\title{
ASSOCIATION OF HYPERLIPIDAEMIA WITH DIABETIC RETINOPATHY
}

\author{
FARUQUE GM ${ }^{1}$, AHSAN K², ANISUDDIN AIM ${ }^{3}$
}

\begin{abstract}
:
Context: Diabetic retinopathy is a major cause of ocular morbidity among the diabetic patient. The aim of this study is to establish that hyperlipidaemia contributes to the development of diabetic retinopathy.

Method: A cross sectional observational Study of 140 consecutive patients of Non insulin dependent diabetis mellitus more then 05 years were included in the study.

Results: 140 NIDDM paticnts and 50 non diabetic control persons. were included in the study. In this study mean serum total cholesterol was $272.33 \mathrm{mg} / \mathrm{dl}, 187.70 \mathrm{mg} / \mathrm{dl}$ and $132.56 \mathrm{mg} / \mathrm{dl}$ respectively. Among the 3 study groups, 58.9\% was diabetic retinopathy patients , 56\% patients without retinopathy and 54\% in non- diabetic controls.. Visual acuity was $0.34,0.08$ and 0.06 respectively.

Conclusion: This study suggests that diabetic retiopathy patients need assessment of serum lipids and they may need lipid-lowering agent to halt the progression of diabetic retinopathy and also to protect the patients from systemic morbidity of hyperlipidaemia.
\end{abstract}

Key words: Hyperlipidaemia, Diabetic Retinopathy.

J Dhaka Med Coll. 2008; 17(2) : 62-66.

\section{Introduction:}

Diabetes mellitus is a metabolic disorder of multiple aetiology, characterized by hyperglycaemia, glycosuria and wide spectrum of clinical and pathological manifestations. The definition and diagnosis of diabetes mellitus have changed considerably in recent years. Diabetes mellitus is now defined as a group of metabolic diseases characterized by hyperglycaemia resulting from defects in insulin secretion, insulin action or both ${ }^{1}$ .Diabetes mellitus is considered as an all organ affecting disease that affects all stages of development also. As it affects almost all organ and tissues of the body, it has been regarded as a Prince of Diseases ${ }^{2}$.According to Dunlop ${ }^{2}$, if a doctor knows diabetes mellitus, he knows medicine. This is one of the remarkable saying about diabetes.

Blinding diabetic eye disease is now one of the fourth major causes of blindness in the world after cataract, glaucoma and trachoma ${ }^{3}$. Diabetic retinopathy is now the leading cause of blindness in persons 25 to 74 years of age ${ }^{4}$.
Diabetes mellitus is associated with damage with the small blood vessels in the retina resulting in loss of vision. In developed societies, it is a major cause of visual disability in people aged 25 years or older. In one study, it was seen that after 15 years of diabetes, 21 percent of diabetic population had visual impairment and 6 percent were legally blind. In another study, diabetic retinopathy was the underlying cause of blindness in 86 percent of the eyes of younger onset group. In older onset group, blindness was due to diabetic retinopathy in 35 percent of eyes, while in remainder, the causes included, cataract, glaucoma and age related macular degeneration 5 .

Diabetic retinopathy and diabetic macular oedema are the leading causes of blindness in the working age group population of most of developed and developing countries. The increasing number of individuals with diabetes worldwide suggests that diabetic macular oedema will continue to be major contributors to vision loss and associated functional

1. Assistant Professor, Department of Ophthalmology, Dhaka Medical College, Dhaka

2. Lecturer, Department of Pathology, Dhaka Medical College, Dhaka.

3. Assistant Professor, Department of Ophthalmology, Sir Salimullah Medical College, Dhaka.

Correspondence : Dr. GM Faruque 
impairment of years to come ${ }^{6}$ It is known that many diabetics have hypercholesterolemia and hypertriglyceridemia ${ }^{7}$. Many studies over the years have suggested a relationship between serum lipid levels and diabetic retinopathy. Dornan et $a l^{7}$ found an association between total serum cholesterol and diabetic retinopathy. This was further substantiated by Miccoli et $a l^{8}$. More recently, the Early Treatment Diabetic Retinopathy Study (ETDRS) group and the Wisconsin Epidemiologic Study of Diabetic Retinopathy found a statistically significant association between elevated serum total cholesterol and low density lipoprotein (LDL) cholesterol and the severity of retinal hard exudation in patients with diabetic retinopathy ${ }^{9}$. The progression to proliferative retinopathy was also shown to be related to serum triglyceride and $\mathrm{LDL}^{10}$

The mechanism by which high serum lipids may cause the progression of diabetic retinopathy is not clearly understood. It has been postulated the elevation of blood viscosity and alterations in the fibrinolytic system occurs in hyperlipidemia causing hard exudates formation. There may also be incorporation of triglycerides into the cell membrane leading to changes in membrane fluidity and leakage of plasma constituents into the retina. This results in haemorrhage and oedema in the retina ${ }^{11}$.

In our country many diabetic retinopathy patients present with profuse hard exudation in the fundus. Many studies suggest an association of diabetic retinopathy with elevated serum lipids. This study has been designed to see the relation of serum lipids (total cholesterol, cholesterol components and triglyceride) with diabetic retinopathy. If any relation between serum lipids and diabetic retinopathy could be established then further management of diabetic retinopathy to halt progression and to reduce exudation could be advocated accordingly.

\section{Materials and Methods:}

This cross sectional observational study was carried out among the diabetic patients attending Dept. of Ophthalmology, BIRDEM and NIO $\& \mathrm{H}$ and age matched non diabetic persons who attended BIRDEM and were investigated to rule out diabetes in the period of July,2004 to September,2006.

Study subjects were allocated to one of the following three groups:

Group I: Diabetic patients with different stages of retinopathy includes 90 patients

Group II: Diabetic patients without retinopathy includes 50 patients

Group III: Non-diabetic control persons includes 50 patients

Criteria for inclusion: Non-insulin dependent diabetes mellitus (NIDDM) patients of both sexes with or without retinopathy and duration of diabetes more than 5 years were included in the study.

\section{Criteria for exclusion:}

- Patients who have had an episode of diabetic ketoacidosis, thyroid or liver disease, non-diabetic renal disease, pregnancy, acute or chronic inflammatory syndrome, alcoholism or malnutrition, were not included in the study.

- Patients on diuretics, ß-blockers, hypolipemic agents, or any other drug or hormone known to influence lipid or lipoprotein metabolism, were not included.

Ophthalmic evaluation: All the study subjects had a thorough ophthalmic evaluation which included slit lamp biomicroscopic examination of anterior segment, direct and indirect ophthalmoscopy for fundus evaluation, colour fundus photographs for documentation, fundus fluorescein angiogram in selected cases for categorization of diabetic retinopathy.

Laboratory procedures: Blood samples were collected from all the study subjects in the morning to carry out the following tests: ${ }^{12}$

i. Serum fasting total cholesterol (Measured by CHOD-PAP photometric test).

ii. Serum fasting triglyceride (Measured by colorimetric enzymatic test using glycerol3- phosphate- oxidase. 
iii. Serum fasting low density lipoprotein.

iv. Serum fasting high density lipoprotein. (Measured by precipitation of LDL,VLDL and chylomicrons.

\section{Results:}

140 NIDDM paticnts and 50 non diabetic control persons. were included in the study.

The mean age of patients in group 1 was 53.88 years and in group II was 52.72 years. Among the study patients, in group- 1, $58.9 \%$ were male and $41.1 \%$ were female. In group II , 56\% were male and $44 \%$ were female. In this study mean deviation was 9.16 years and 9.32 years respectively. Visual acuity was $0.34,0.08$ and 0.06 respectively.In my study mean serum total cholesterol was $272.33 \mathrm{mg} / \mathrm{dl}, 187.70 \mathrm{mg} / \mathrm{dl}$ and $132.56 \mathrm{mg} / \mathrm{dl}$ respectively. Among the 3 study groups , $58.9 \%$ was diabetic retinopathy patients, $56 \%$ patients without retinopathy and $54 \%$ in non- diabetic controls. In diabetic retinopathy patients, mean serum triglyeeride level was $282.43 \mathrm{mg} / \mathrm{dl}$, in diabetic patients without retinopaty, mean serum triglyceride was $155.84 \mathrm{mg} / \mathrm{dl}$ and in non - diabetic patients it was $132.56 \mathrm{mg} / \mathrm{dl}$.In diabetic retinopaty patients, mean serum LDL level was 194.75 $\mathrm{mg} / \mathrm{dl}$, in diabetic patients without retinopathy, mean serum LDL was $97.52 \mathrm{mg} / \mathrm{dl}$ and in nondiabetic patients it was $92.62 \mathrm{mg} / \mathrm{dl}$, Mean serum HDL level was $38.61 \mathrm{mg} / \mathrm{dl}$, in diabetic retinopathy patients, $53.16 \mathrm{mg} / \mathrm{dl}$ and in diabetic patients without retinopathy and 57.42 $\mathrm{mg} / \mathrm{dl}$ in non - diabetic patients.

Statistical analysis was done by ANOVA(F) test and 't' upaired test.

\section{Table-I}

Distribution of mean age of study subjects

\begin{tabular}{lc}
\hline Study group & $\begin{array}{c}\text { Mean age in years } \\
\pm \mathrm{SD}\end{array}$ \\
\hline Group I $(\mathrm{n}=90)$ & $53.88 \pm 6.55$ \\
Group II $(\mathrm{n}=50)$ & $52.72 \pm 7.00$ \\
Group III $(\mathrm{n}=50)$ & $54.92 \pm 7.38$ \\
\hline
\end{tabular}

Table - II

Distribution of duration of diabetes among the patients under Group I and Group II

\begin{tabular}{lcccc}
\hline $\begin{array}{l}\text { Duration of } \\
\text { diabetes }\end{array}$ & \multicolumn{2}{c}{$\begin{array}{c}\text { Group-I } \\
(\mathrm{n}=90)\end{array}$} & \multicolumn{2}{c}{$\begin{array}{c}\text { Group-II } \\
(\mathrm{n}=50)\end{array}$} \\
year & No. of case & $\%$ & No. of case & $\%$ \\
\hline $5-10$ & 74 & 82.2 & 40 & 80 \\
$>10$ & 16 & 17.8 & 10 & 20 \\
Mean \pm SD & $9.16 \pm 2.67$ & 9.32 & \pm 3.00 \\
\hline
\end{tabular}

Table-III

Distribution of visual acuity of the study subjects expressed in logMAR unit

\begin{tabular}{lcr}
\hline Study group & Mean visual acuity & p value \\
\hline Group I $(n=90)$ & 0.34 & $<0.001^{* * *}$ \\
Group II $(n=50)$ & 0.08 & \\
Group III $(n=50)$ & 0.06 & \\
\hline
\end{tabular}

t' unpaired between Group - I \& II = $13(p<0.001)$

' $\mathrm{t}$ ' unpaired between Group - I \& III = $14(\mathrm{p}<0.001)$

' $\mathrm{t}$ ' unpaired between Group - II \& III = $02 \quad(\mathrm{p}<0.05)$

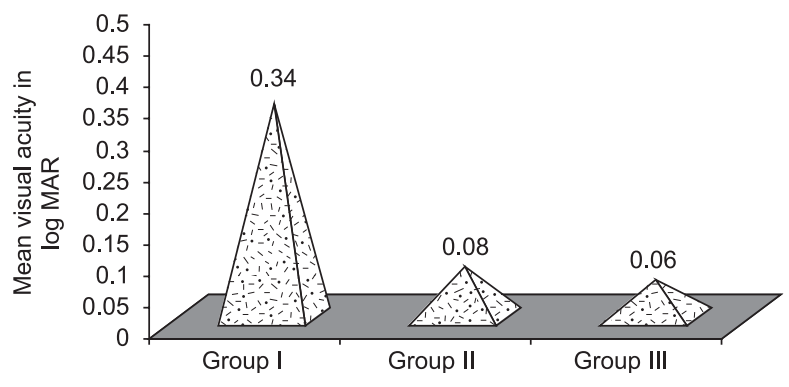

Fig. 1: Bar diagram showing distribution of visual acuity of the study subjects expressed in log MAR.

Table-IV

Distribution of serum total cholesterol level of the study subjects expressed in $\mathrm{mg} / \mathrm{dl}$.

\begin{tabular}{lc}
\hline Study group & $\begin{array}{c}\text { Mean serum total } \\
\text { cholesterol level }(\mathrm{mg} / \mathrm{dl})\end{array}$ \\
\hline Group I & 272.33 \\
Group II & 187.70 \\
Group III & 185.92 \\
\hline t' unpaired between Group - I \& II $=10.34 \quad(\mathrm{p}<0.001)$ \\
't' unpaired between Group - I \& III $=10.20 \quad(\mathrm{p}<$ \\
O.001) \\
't' unpaired between Group - II \& III $=0.31 \quad(\mathrm{p}>0.05)$
\end{tabular}


Table-V

Distribution of serum triglyceride level of the study subjects expressed in $\mathrm{mg} / \mathrm{dl}$.

\begin{tabular}{lc}
\hline Study group & $\begin{array}{c}\text { Mean serum triglyceride } \\
\text { level }(\mathrm{mg} / \mathrm{dl})\end{array}$ \\
\hline Group I & 282.43 \\
Group II & 155.84 \\
Group III & 132.56 \\
\hline
\end{tabular}

't' unpaired between Group - I \& II = $13.59(\mathrm{p}<0.001)$ 't' unpaired between Group - I \& III = $18.64(\mathrm{p}<$ $0.001)$

't' unpaired between Group - II \& III = $2.63(\mathrm{p}<0.05)$

Table-VI

Distribution of serum low density lipoprotein level of the study subjects expressed in $\mathrm{mg} / \mathrm{dl}$.

\begin{tabular}{lc}
\hline Study group & $\begin{array}{c}\text { Mean serum low density } \\
\text { lipoprotein level }(\mathrm{mg} / \mathrm{dl})\end{array}$ \\
Group I & 194.75 \\
Group II & 97.52 \\
Group III & 92.62 \\
\hline 't' unpaired between Group - I \& II $=13.21 \quad(\mathrm{p}<$ \\
O.001) \\
't' unpaired between Group - I \& III $=13.56(\mathrm{p}<$ \\
O.001) \\
't' unpaired between Group - II \& III $=0.83 \quad(\mathrm{p}>$ \\
0.05)
\end{tabular}

\section{Discussion:}

Diabetic retinopathy is a common blinding disease of the eye. Diabetic retinopathy often presents with marked hard exudation in the fundus which is called exudative diabetic retinopathy ${ }^{10}$. Hard exudate is one of the important cause of poor vision in diabetic retinopathy. Even after appropriate laser vision sometimes does not improve due to residual hard exudates in the macula ${ }^{11}$. That was the reason why diabetic retinopathy with marked hard exudation was taken into account in this study.Diabetic patients often have hypercholesterolemia and hypertriglyceridemia ${ }^{4}$. Many studies over the years have suggested a relationship between serum lipid levels and diabetic retinopathy. Dornan et $a l^{5}$. found an association between total serum cholesterol and diabetic retinopathy. This was further substantiated by Miccoli et $a l^{6}$. More recently, the Early Treatment Diabetic Retinopathy Study (ETDRS) group and the Wisconsin Epidemiologic Study of Diabetic Retinopathy found a statistically significant association between elevated serum total cholesterol and low density lipoprotein ( LDL) cholesterol and the severity of retinal hard exudation in patients with diabetic retinopathy ${ }^{7}$. The progression to proliferative retinopathy was also shown to be related to serum triglyceride and $\mathrm{LDL}^{8}$.

In this study all the patients had thorough ophthalmic examination and was grouped into either of diabetic patients with diabetic retinopathy (Group-I), diabetic patients without diabetic retinopathy (Group-II) and non-diabetic controls (Group III). Fundus picture of Group-I revealed variable amounts of hard exudates, haemorrhages and other features of diabetic retinopathy. Fundus appearance of Group-II revealed no such features suggestive of diabetic retinopathy. On the other hand, Group III patients were non-diabetic and fundus were free any sorts of retinopathies. In this study maximum patients included in 40-50 years age group. Mean age in Group-I was 53.88 years and in Group-II was 52.72 years. In the study of Brown et al ${ }^{10}$. mean age was 48 years ranging from 32-61 years. In the study of Larsson et $a l^{13}$ age range was $15-50$ years. They included both IDDM and NIDDM patients where the current study included only NIDDM patients.

Among the study patients, in Group-I, 58.9\% patients were male and $41.1 \%$ were female. In Group-II, 56\% were male and 44\% were female. Reason behind increased number of male patients may be the social status where, male gets priorities. In the study of Gupta et al ${ }^{14}$.male proportion was also higher.

In the current study, mean duration of diabetes was 9.16 years in Group - I and 9.32 years in Group - II. In the study of Brown et al ${ }^{10}$ it was 10.8 years ranging from $4-14$ years. In the study of Miccoli et al ${ }^{6}$ mean duration of diabetes was 13 years. Guerci et $a l^{12}$ showed mean duration of diabetes 20 years; but all of his study patients had IDDM having early onset of diabetes.

Visual acuity is affected by hard exudates in the macula. In the current study Visual acuity 
was expressed in log MAR unit. In Group -I patients mean visual acuity was 0.34 , in Group - II patients visual acuity was better (0.08) and in Group - III patients it was far better (0.06). Hard exudation along with macular oedema is an important cause of visual deprivation in patients with diabetic retinopathy. Visual acuity was measured by Snellen chart and converted to log MAR values after Sihota \& Tandon ${ }^{15}$. In the study of Brown et $a l^{10}$ most of the patients had visual acuity worse than +1.0. In the study of Chew et $\mathrm{al}^{3}, 60 \%$ patients had visual acuity worse than $0.3(6 / 12)$.

In the current study mean serum total cholesterol was $272.33 \mathrm{mg} / \mathrm{dl}$ in Group - I patients, $187.70 \mathrm{mg} / \mathrm{dl}$ in Group - II patients and $185.92 \mathrm{mg} / \mathrm{dl}$ in Group - III patients. This result is similar to Brown et $a l^{10}$ who reported mean serum cholesterol level in retinopathy group $338 \mathrm{mg} / \mathrm{dl}$ and in control group $247 \mathrm{mg} /$ d1. Chew ${ }^{16}$ showed that patients with serum cholesterol level more than $240 \mathrm{mg} / \mathrm{dl}$ were twice as likely to have more hard exudates as those patients with serum cholesterol level 200 $\mathrm{mg} / \mathrm{dl}$. Chew ${ }^{16}$ showed that moderate to severe exudative diabetic retinopathy patients had serum cholesterol above $240 \mathrm{mg} / \mathrm{dl}$. Miccoli et $a l^{6}$ found mean serum cholesterol level 212 $\mathrm{mg} / \mathrm{dl}$ in exudative retinopathy patients.

The study shows, mean serum triglyceride level was $282.43 \mathrm{mg} / \mathrm{dl}$, in Group-II, mean serum triglyceride was $155.84 \mathrm{mg} / \mathrm{dl}$ and in Group III it was $132.56 \mathrm{mg} / \mathrm{dl}$. Brown et al ${ }^{10}$ found serum triglyceride level quite higher than the current study; that was $832 \mathrm{mg} / \mathrm{dl}$ (mean value) in retinopathy group and $113 \mathrm{mg} /$ $\mathrm{dl}$ in the control group.

\section{Conclusion:}

Analytical result of this study reveals that the patients of diabetic retinopathy have been found to have close association with elevated serum lipid levels. This study suggests that diabetic retinopathy patients need assessment of serum lipids and they may need lipid-lowering agent to halt the progression of diabetic retinopathy and also to protect the patients from systemic morbidity of hyperlipidaemia.

\section{References:}

1. Klein R, Klein BE, Moss SE. Association of ocular disease and mortality in a diabetic population. Arch Ophthalmol. 1999; 117: 1487-95.
2. Dunlop. A prince of diseases: a review. BMJ 1960; 5: 432.

3. Chew EY, Klein ML, Ferris FL 3rd, Remaley NA, Murphy RP, Chantry K, Hoogwerf BJ, Miller D. Association of elevated serum lipid levels with retinal hard exudate in diabetic retinopathy. Early Treatment Diabetic Retinopathy Study (ETDRS) Report 22. Arch Ophthalmol. 1996; 114(9): 107984.

4. Kern PA. Lipid disorders in diabetes mellitus. Mt Sinai J Med 1987-54: 245-252. King H, Rewers M. Diabetes in adults is now a third world problem. Comm Eye Health. 1996; 9: 51-3.

5. Dornan TI, Carter RD, Bron AJ, Turner RC, Mann JI. Low density lipoprotein cholesterol: an association with the severity of diabetic retinopathy. Diabetologia. 1982; 22: 167-70.

6. Miccoli R, Odello G, Giampietro O, Marchetti P, Cristofani R, Penno G, Meucci G, Navalesi R. Circulating lipid levels and severity of diabetic retinopathy in type I diabetes mellitus. Ophthalmic Res. 1987; 19(1): 52-6.

7. Ferris III FL, Chew KY, Hoogwerf HJ. Serum lipids and diabetic retinopathy. Early reatment diabetic retinopathy study research group. Diabetes Care 1996; 19: 1291.

8. Lloyd CE, Klem R, Maser RE, Kuller LH, Becker DJ, Orchard TJ. The progression of retinopathy over 2 years: the Pittsburgh Epidemiology of Diabetes Complications (EDC) Study. J Diabetes \& its Complications 1995; 9: 140-8.

9. Freyberger H, Schifferdecker E, Schatz H. Ruckbildung harter Exsudate hei diabetischer Hintergrundretinopathie unter Therapie mit dem Lipidsenker Etofibrat. Medizinische Klinik. 1994; 89: $594-7$

10. Brown GC, Ridley M, Haas D, Lucier AC, Sarin LK. Lipemic diabetic retinopathy. Ophthalmology 1984; 91:1490 1495. Chew EY. Diabetic retinopathy and lipid abnormalities. Curr Opin Ophthal. 1997; 8: 59-62.

11. Su DHW, Yeo KT. Diabetic retinopathy and serum lipids. Singapore Med J. 2000; 4: 295-7.

12. Guerci B, Meyer L, Sommer S, George JL, Ziegler O, Drouin P, Angioi-Duprez K. Severity of diabetic retinopathy is linked to lipoprotein (a) in type 1 diabetic patients. Diabetes Metab. 1999; 25(5): 412-8.

13. Larsson LI, Alm A, Lithner F, Dahlen G, Bergstrom $\mathrm{R}$. The association of hyperlipidemia with retinopathy in diabetic patients aged $15-50$ years in the county of Umea. Acta Ophthalmol Scand. 1999; 77(5): 585-91.

14. Gupta A, Gupta V, Thapar S, Bhansali A. Lipidlowering drug atorvastatin as an adjunct in the management of diabetic macular edema. Am J Ophthalmol. 2004;137(4): 675-82.

15. Sihota R, Tandon R. Parson's Diseases of the Eye, $19^{\text {th }}$ edition, Butterworth Heinmann, 2003; p. 93-5.

16. Chew EY,Diabetic retinopathy and lipid abnormalities.Curr Opin Ophtthal. 1997; 8: 59-62. 